\title{
Downturn Remains Mild
}

\author{
by NORMAN N. BOWSHER
}

M

EASURES TAKEN TO COOL the overheated economy appear to be bearing some results. Growth of spending has moderated over the past year, reducing "demand-pull" pressures for resources and on prices. Reduction of excessive total demands and accelerating inflation of necessity always involves costs in the form of foregone production and continued price increases for an extended time. The alternative of continued accelerating inflation for prolonged periods is clearly unacceptable. An objective of current stabilization policy has been to take actions which will reduce inflation and restore stable economic growth, while minimizing the costs of the transition.

The current inflation accelerated markedly from 1964 to 1969 . Overall prices, which had been rising less than $1 \frac{1 / 2}{2}$ per cent a year in the early 1960 's, increased 2 per cent in $1965,3.5$ per cent a year in 1966 and 1967, 4 per cent in 1968, and 5 per cent in 1969. The accelerating inflation reflected a rise in total demands for goods and services at an average 8 per cent annual rate from late 1964 to late 1969, or roughly double the rise in productive capacity. The excessive rise in total spending was fostered in large part by expansive monetary and fiscal actions from 1964 through 1968.

In an attempt to restrain total spending and price inflation, fiscal actions became less expansionary in mid-1968 and monetary actions in early 1969. As a result, spending growth has slowed markedly since early last fall to a rate approximating the rising trend of productive capacity. The upward momentum of prices has continued virtually unabated despite the lessening of demand pressure and cutbacks have occurred in production.

In this article recent economic developments are compared with conditions after past peaks in economic activity to gain some insight into the costs incurred and progress made in combatting inflation. ${ }^{1}$

1The last three peaks in economic activity selected by the National Bureau of Economic Research are May 1960, July 1957, and July 1953. In addition we note two other slowdowns in activity, beginning October 1966 and July 1962.
August 1969 is used as a tentative peak for the current period, since it is the middle month of the quarter when real output was greatest. ${ }^{2}$ The pause in spending, production and employment has been much more moderate than in the 1954, 1958, and 1960 recessions, and more nearly like the pauses of 1962 and 1966.

\section{Sponting}

Growth in spending in recent quarters has been much greater than after the three previous cyclical peaks, and about the same as after the 1962 and 1966 hesitations in economic activity (Table I). From

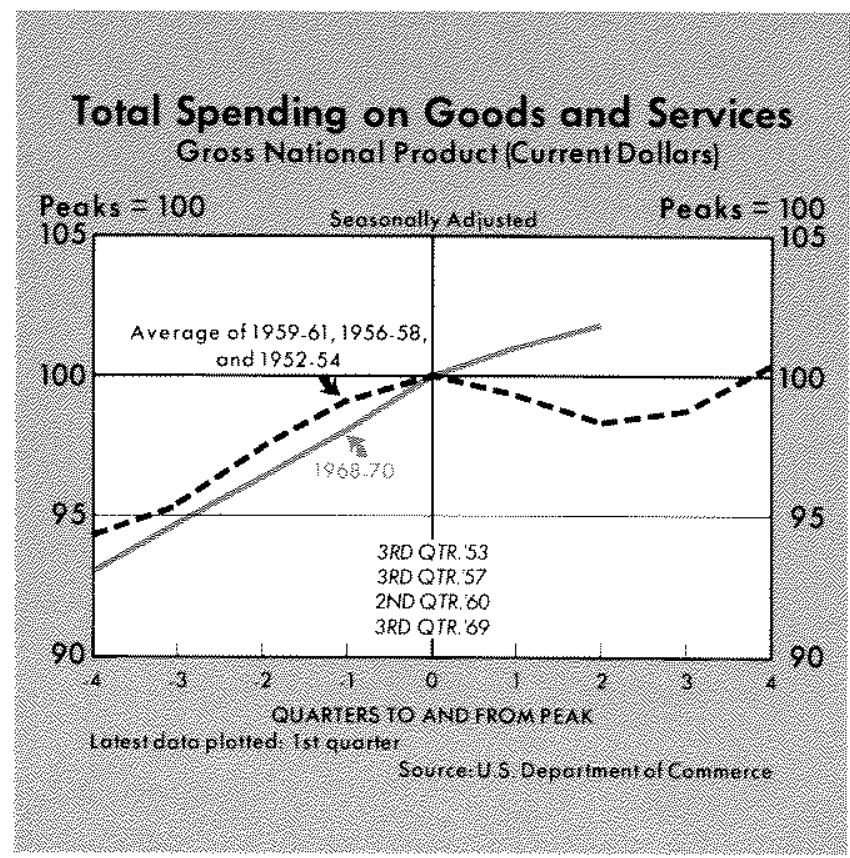

the third quarter last year to the first quarter this year total spending rose at a 3.6 per cent annual rate. During the first two quarters of the three previous business recessions, total spending declined at an average 2.8 per cent rate. In the first two quarters of the 1962 and 1966 pauses in activity, total spending rose at an average 4 per cent rate.

'Any other month from last July to Novenber might have been selected. 


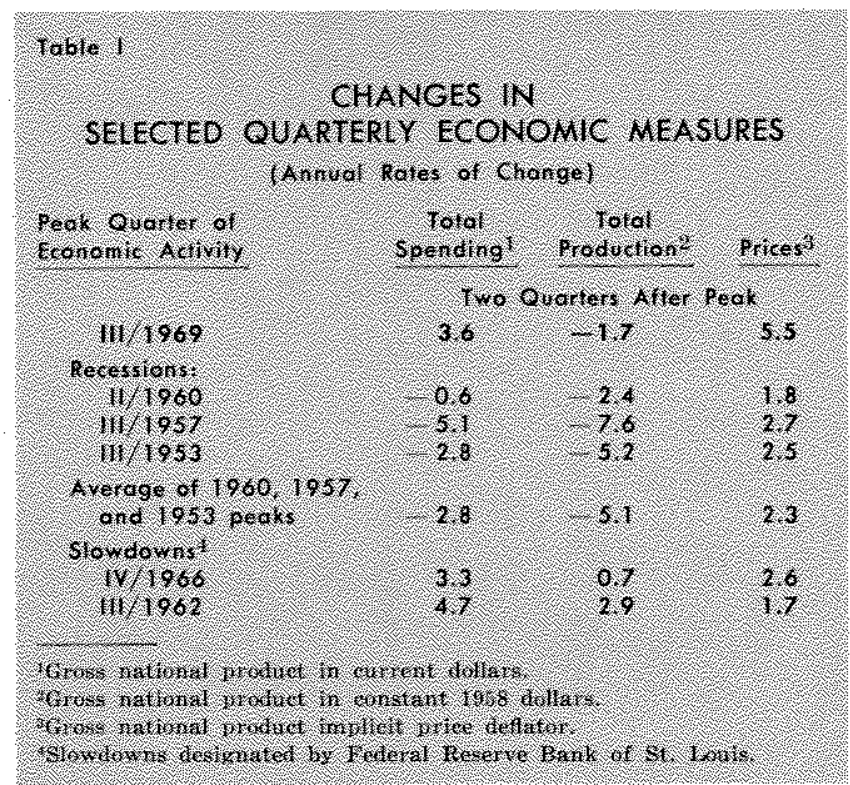

\section{Priceg}

More of the growth in spending in late 1969 and in 1970 was reflected in higher prices than after previous cyclical peaks. Overall prices (Table I) rose 5 per cent in the year ending with the third quarter last year, and have increased at a slightly faster rate since that quarter (reportedly a 5.5 per cent annual rate, retroactively including portions of Government wage increases). In the year preceding the peaks of the previous three recessions, prices rose at an average of 2 per cent, and in the following two quarters at an average 2.3 per cent annual rate.

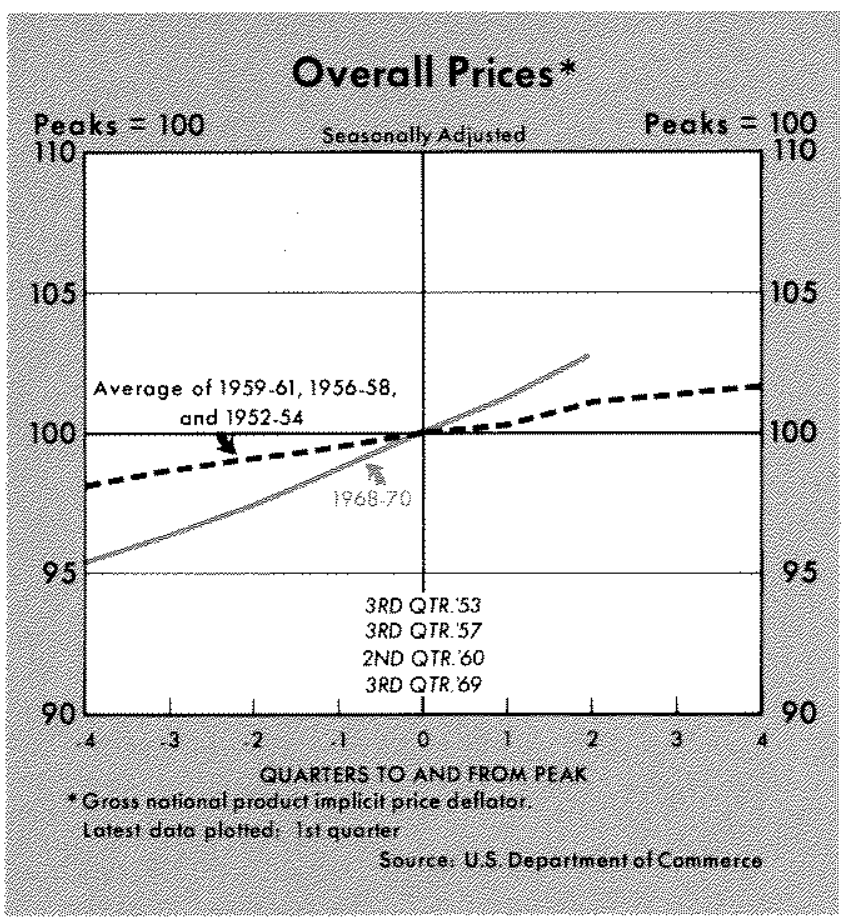

Upward momentum of prices has been strong and persistent in the three recessions. Price increases not only intensified somewhat for a period of six months or more after the excessive demand was eliminated, but inflation usually persisted for several additional years, although at a moderating rate. Many prices and wages do not adjust upward at the time of the most intensive demand pressure. This may be due to inertia, lack of knowledge of costs, public opinion, regulations, or contracts. These lagging price adjustments place "cost-push" forces on other prices when they do occur. Consequently, success in the struggle against inflation typically takes a long period.

\section{Traduction}

Real product, like total spending, has reacted much less in this pause than in the three recessions. From the assumed peak last August to the first quarter this year, real production declined at a 1.7 per cent annual rate, while in each of the first two quarters after the three previous cyclical turns, production contracted much more sharply, averaging a -5.1 per cent rate (Table $\mathrm{I}$ ).

Industrial production, like total real product, has changed much less than in the three recessions. The decline in industrial production at a 3.3 per cent rate from last August to April was much more modest than during the first eight months of any of the three previous recessions, when production fell at an average 14 per cent rate (Table II).

Employment trends also have been stronger in late 1969 and early 1970 than following the upper turning points of the three earlier cycles (Table II). Since last August employment has increased at a 1 per cent rate, whereas in the first eight months of

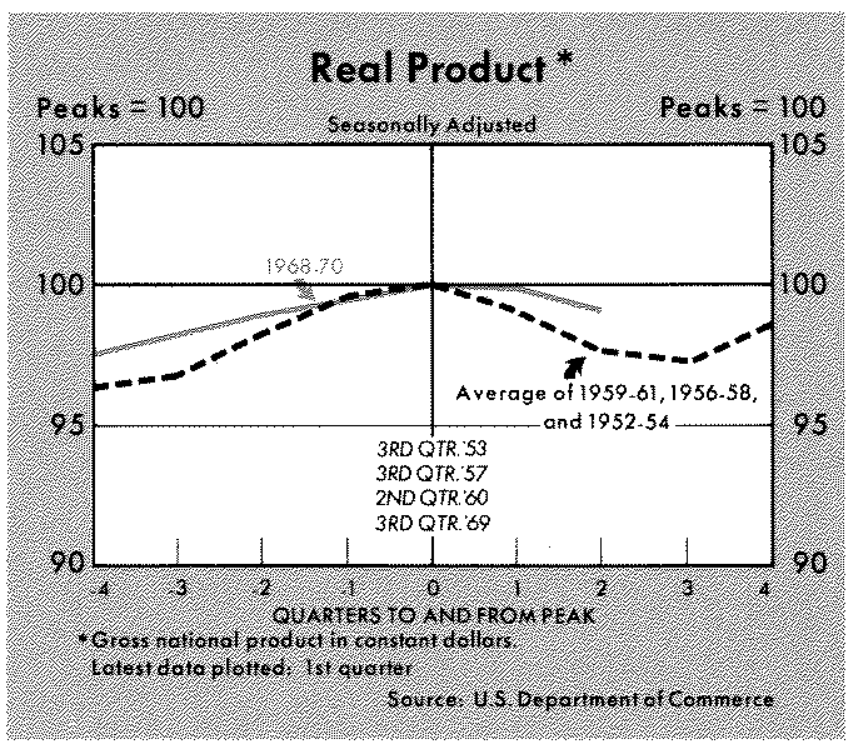




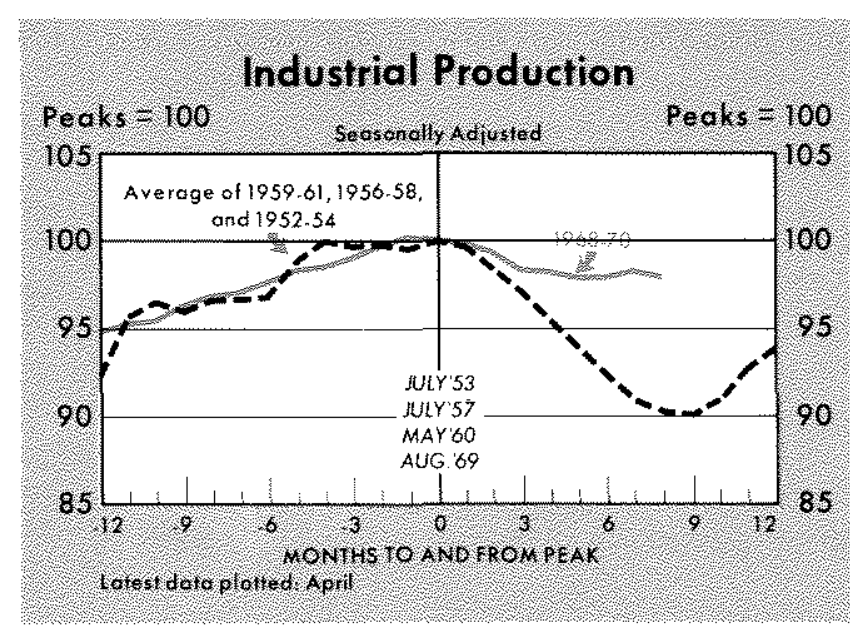

each of the three previous recessions, it had declined at an average rate of 3.8 per cent.

A greater portion of the population is now working than at a comparable stage in earlier economic slowdowns. In April the number employed was equal

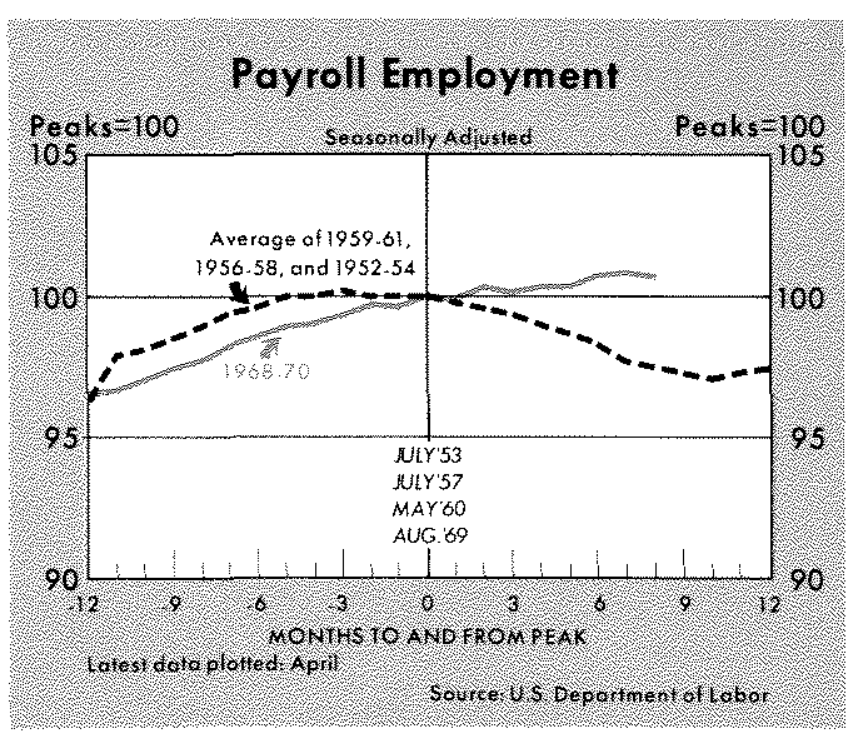

to 64.7 per cent of the population of working force age (16 through 64 ), about the same as at the assumed peak last August. From 1950 to late $1965 \mathrm{em}$ ployment ranged between 60 and 63.4 per cent of population of working force age, as shown in the accompanying chart.

Other indicators of economic activity, both nominal and real, generally confirm the evidence that the economy's performance has been stronger in the recent past than at a comparable stage in previous economic pauses. Personal income rose more rapidly after August 1969 than in the like periods following May 1960, July 1957, and July 1953 (Table II). Construction expenditures, adversely affected by financial disintermediation and usury

\section{Tolal Civilian Employment} Per Cen ol Totol Populotion of Working Eorce Ag 16.64

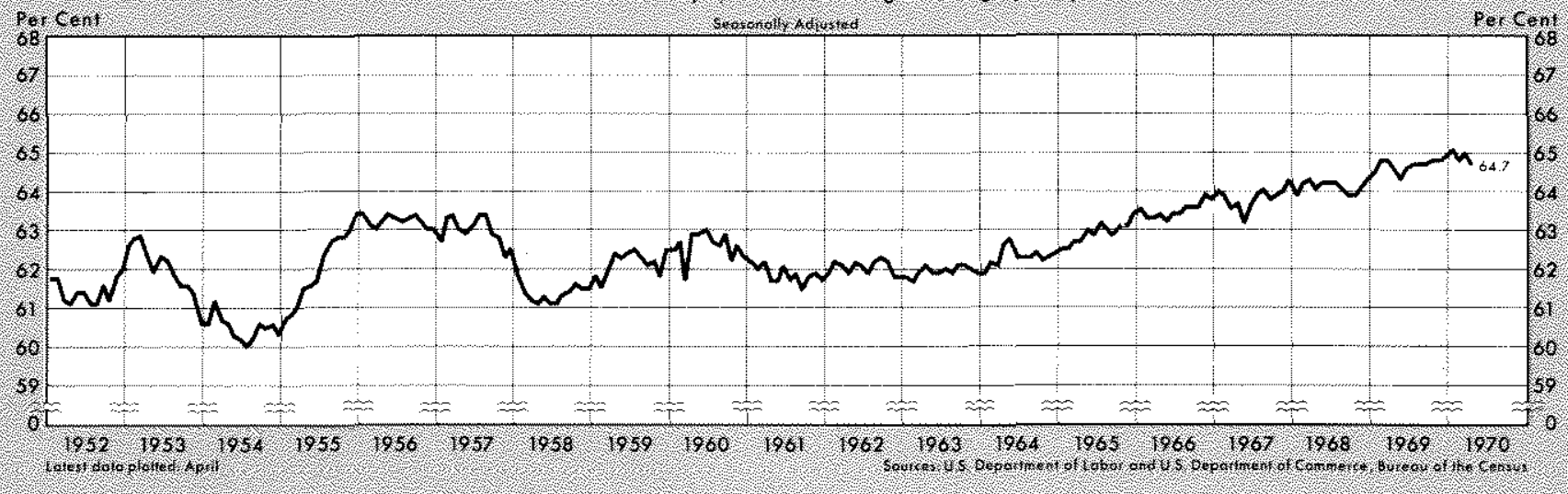




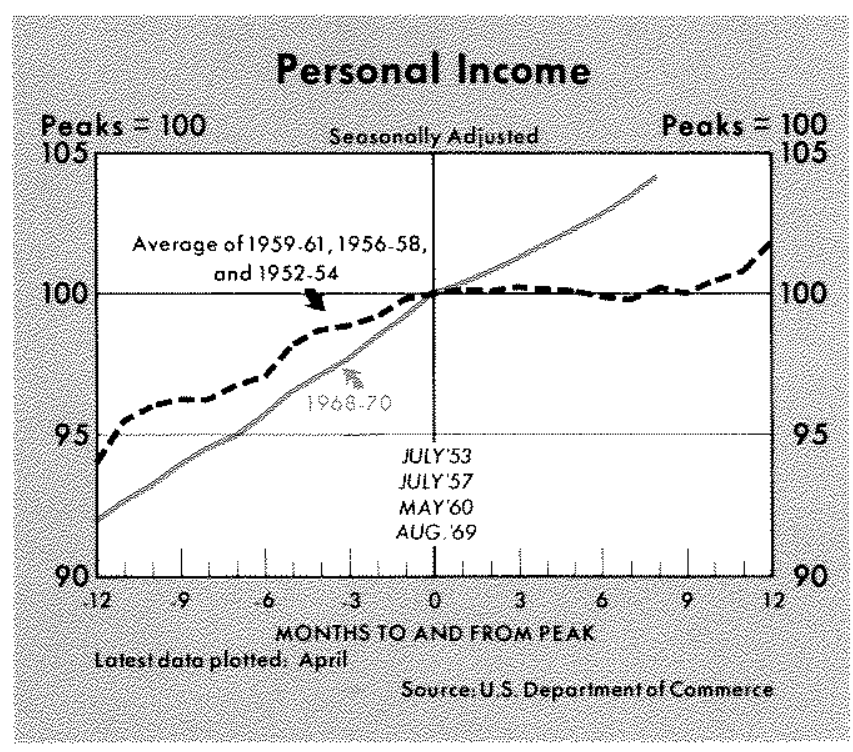

laws in the past year, were weaker than after the 1953 and 1960 peaks but were stronger than in the corresponding months after the 1957 peak. Unemployment rates in 1970 have been lower than at corresponding periods in other recessions.

Retail sales have risen at roughly a 3 per cent annual rate since last August, about the same rate of expansion as in the previous year. In the corresponding eight months after the three recessions, retail sales declined at about a 3 per cent average rate. Corporate profits after taxes declined at a 14 per cent annual rate from the third quarter last year to the first quarter this year, about half the average rate of

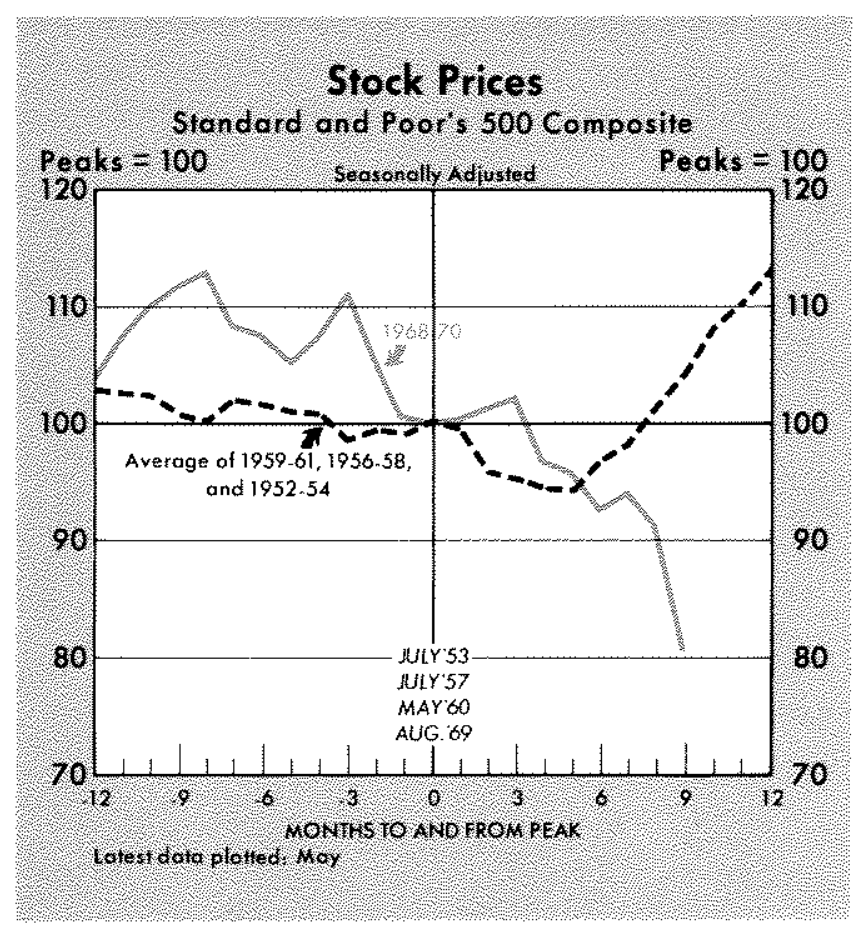

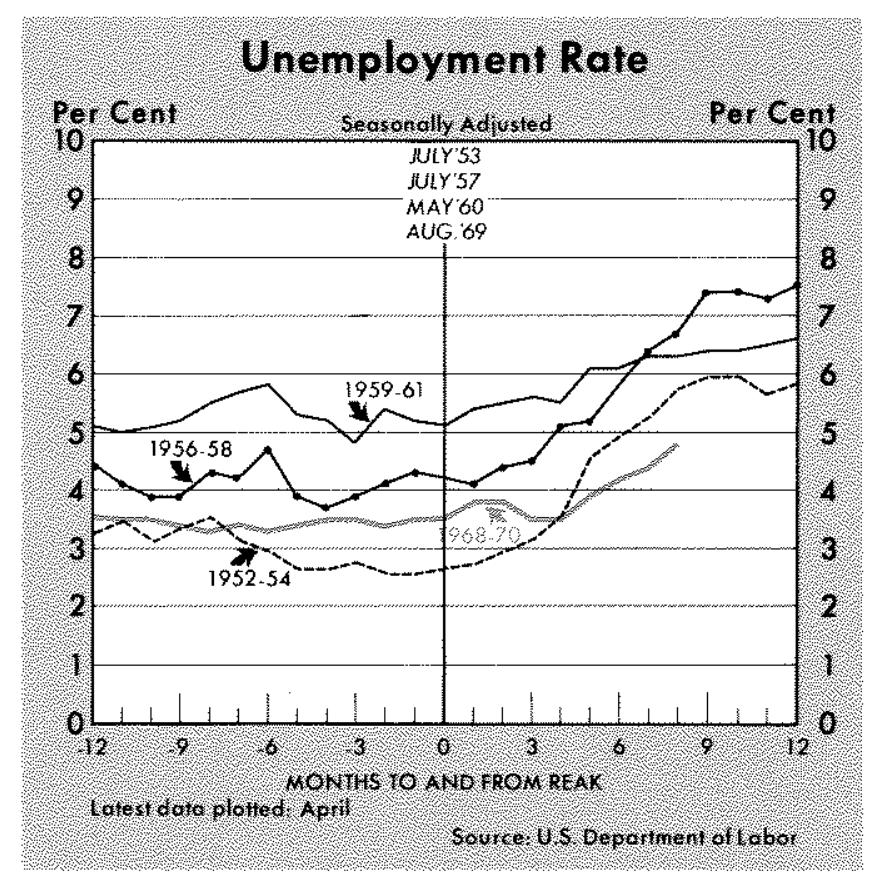

decline in the comparable two quarters of the three recessions.

Both stock and bond prices declined (yields rose) from last August to May, while they increased in the corresponding period of other recessions. Stock prices, as measured by the Standard and Poor's $500 \mathrm{com}$ posite, declined 19 per cent from last August to May. In the first nine months of the three previous recessions, stocks rose an average 5 per cent. Interest rates on highest grade corporate bonds rose 16 per cent

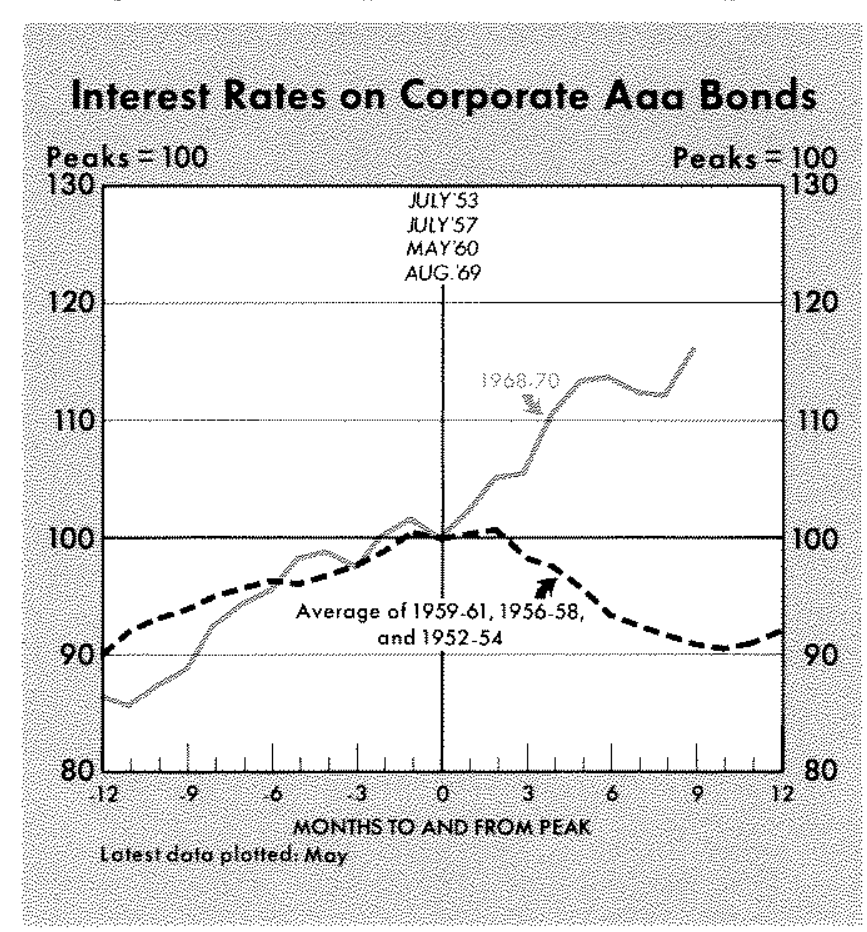


from August to May, compared with an average 9 per cent decline in the corresponding period of the three previous recessions. The rise in yields during the current slowdown probably refects rising inflationary expectations following from the five-year acceleration of prices. ${ }^{3}$

\section{wiscal Conumbus}

Government fiscal actions have not been uniform around cyclical peaks. Both before and after the 1960 peak, fiscal actions, as measured by the high-employment budget, were quite restrictive. Around the 1957 peak, fiscal actions were moderately restrictive. In

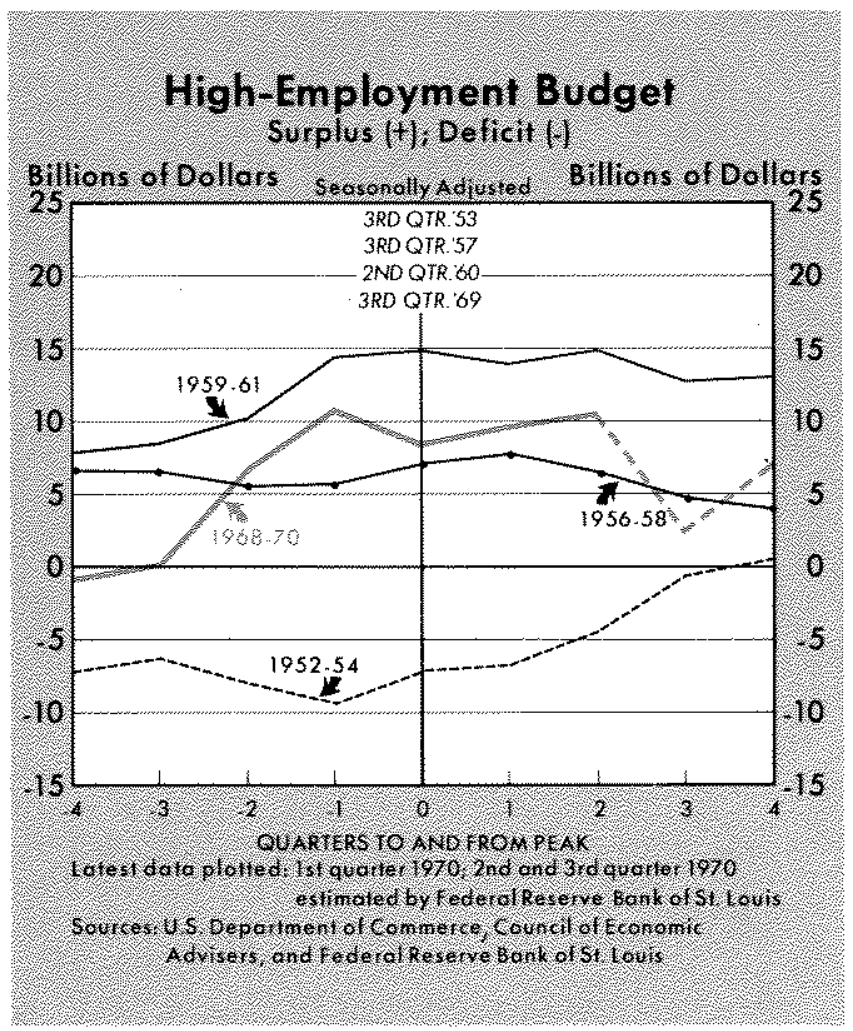

contrast, fiscal actions in the year before the 1953 peak were stimulative, and became progressively less expansionary during the following recovery.

Fiscal actions changed from a stimulative to a restrictive stance more than a year before August 1969 , with the imposition of the 10 per cent surtax in mid-1968 and some slowing in the rate of Government spending growth. The sharpest changes in spending growth were in the defense sector, where outlays contracted slightly after mid-1968 after rising at a 17 per cent annual rate in the previous three years. Nondefense Government spending has risen at

3See William P. Yohe and Denis S. Karnosky "Interest Rates and Price Level Changes, 1952 69," this Review (December 1969), pp. 18-38. a 10 per cent rate since mid-1968, following a 13 per cent rate of expansion from mid-1965 to mid-1968.

Since the first quarter of 1969 , the high-employment surplus, as estimated by this bank, has been in the $\$ 7$ to $\$ 11$ billion range. Current expectations are that this surplus will decline only moderately during the summer and fall, although recent actions have caused the anticipated surplus to be slightly less than expected in the January budget. The budget surplus during 1969 and 1970 has been far less in relation to total spending than in the $1961-64$ period, when the nation recovered from recession and experienced balanced economic growth.

\section{Monetary Developmens}

Monetary actions, as measured by the growth of the money stock, were relatively restrictive prior to each of the four peaks and the two slowdowns. On average, the money stock was virtually unchanged for about nine months before the three previous business cycle peaks. In the seven months before August 1969 , money rose at a 2.8 per cent rate. This was faster than immediately before any of the three recessions, but was considerably slower than the 7 per cent rate of increase during 1967 and 1968.

The general trend of the money stock following the peaks of economic activity has been little change for a brief period and then rapid rise. According to one view, these developments may have intensified reces. sions for a period, and then contributed to an excessive rise in total spending and a resurgence of inflation. On average, money remained virtually unchanged during the first six months following the

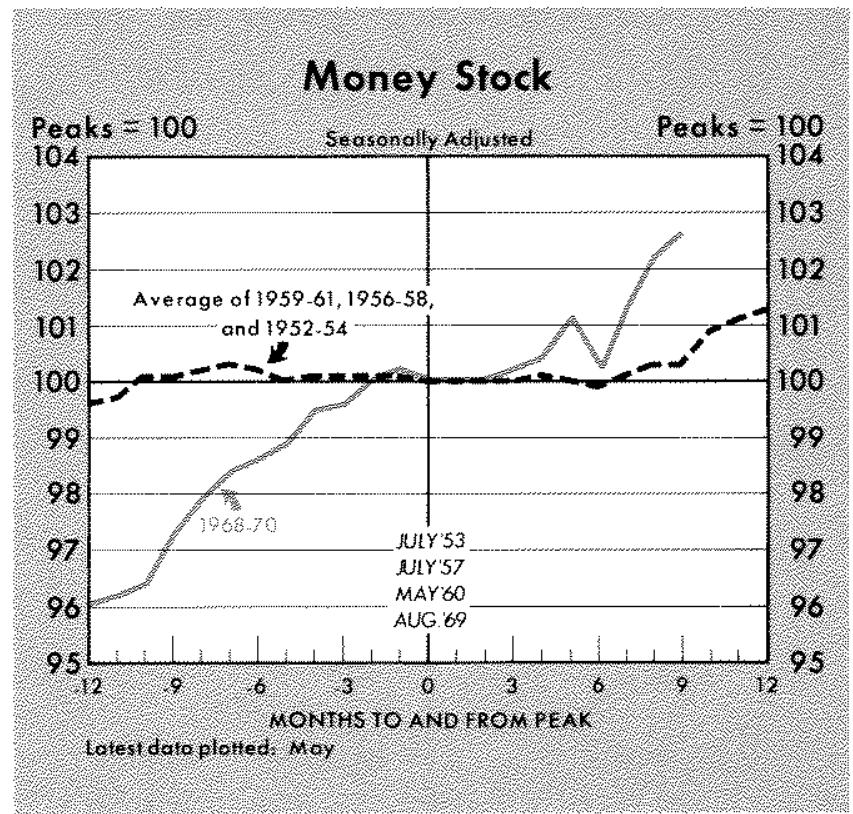


May 1960, July 1957, and July 1953 peaks. In the subsequent three months money rose at an average 1 per cent annual rate, and then began expanding at a faster 3 per cent average rate (compared with a 1.8 per cent trend over the entire 1953 to 1964 period).

Since August 1969, money has followed a similar, but more pronounced, pattern than in the corresponding periods after the three previous business cycle peaks. In the first six months, from August to February, money remained about unchanged, except for a temporary bulge around year-end. From February to May money rose at a very rapid 10 per cent annual rate, or in the 98th percentile of all consecutive threemonth rates of change since early 1950 . This was much faster than during the earlier recessions, and even greater than after the mini-recession in early 1967.

\section{Conchusions}

The current hesitation in economic activity has been more moderate than in the corresponding periods of the three previous recessions we have discussed. Total spending and other nominal measures of economic activity have been much stronger recently than after other cyclical peaks. Comparisons using such measures have lost some of their meaning in view of the much more rapid recent rate of inflation. Nevertheless, most real measures of output and employment also indicate that the economy has recently been stronger than in the corresponding periods after the three previous cyclical peaks.

Progress in reducing the rate of price increase has been slow. Prices are still being affected by the lagged impacts of previous excesses. Some prices have been restrained by regulation (public utility rates), by contracts (prices of some materials and labor services), by public opinion, by inertia, or by a money illusion. When these prices adjust upward, cost-push pressures are placed on other prices. Previous experience indicates that because of the slow response of some prices, and cost-push pressures, the momentum of inflation generally continues for several years after excessive demands have been eliminated.

Since the inflation generated in the 1965 through 1968 period is much more severe than in any other period since the early 1950 's, and since the restraint on total spending has been less than in other periods of correction, it is likely to require a longer period than usual to correct, particularly if the costs in terms of lost production are to be at a moderate level. Hence, even though the current economic slowdown has been milder than previous recessions, it may last longer, especially if substantial progress is to be made in the struggle against inflation.

Questions arise as to whether some alternative policies or tools might better accomplish the desired results. Some feel that monetary and fiscal actions are too slow or clumsy for pursuing the objective of reasonable price stability. It has been suggested that the fight against inflation might be facilitated by wage, price and credit controls, either by law or by use of moral suasion. Controls raise serious questions of administration and enforcement, reduce freedom of decision for the individual, and cause misallocation of resources. ${ }^{4}$ Such controls are no substitute for proper monetary and fiscal actions, and probably do not hasten the adjustment to price stability even when proper stabilization policies are followed. Many upward price adjustments to restore normal price relations are made long after excessive demand pressures are removed because some prices are inflexible in the short-run. Controls add to the inflexibility, and reduce further the efficiency of the economic system. Con trols also raise questions of equity and efficiency between those sectors where prices are freely flexible, and have already adjusted, and those sectors where rigidities have held back price adjustments.

4"Selective Credit - No Substitute for Monetary Restraint," this Review (December 1969), pp. 13-17. 